\title{
Association between motor development of typical children and head and trunk alignment
}

\author{
Micheli Martinello', Maria W. Louzada², Tamiris B. Martins', Aline D. Rafael', Gilmar M. Santos', Cintia Johnston².
}

\begin{abstract}
Introduction: Among the typical motor development, it is considered the neck control as being of great importance. Although there is no consensus of the best positioning for stimulation of neck control, it is clear in the literature the positive association between the prone position and the typical motor development according to the age of infants. Objective: To investigate the association between the kinematic variables related to neck control and bracing with age and motor performance in the prone position of typical children. Methods: 30 children participated in the study. Motor development was assessed by Alberta Infant Motor Scale (AIMS), and the alignment of the head, trunk and upper limb was analyzed through kinematic analysis in the prone position. Results: with the association of the variables: age, AIMS in the prone position and the kinematic variables (inclination of the head, trunk extension, shoulder angle and elbow angle), was observed that the increase in age and the best performance in the prone position corresponding to the inclination of the head. The trunk and elbow extension also increases. Conclusion: there was a positive association between the variables age and motor performance in the prone position of typical children, with kinematics variables the inclination of the head, the trunk and the elbow extension.
\end{abstract}

Keywords: Child. Child Development. Posture.

\section{INTRODUCTION}

Currently, considered as a country in aging process, Brazil has pointed out major changes in its population. ${ }^{(1)}$ Despite the decrease in birth and infant mortality rates, ${ }^{(2)}$ the life expectancy rates at birth has increased significantly, which allows us to believe in a better quality of life in the country. ${ }^{(1)}$

This advance has a direct influence on child population, which represented $42 \%$ of the general population in 2009 and $8.5 \%$ are children aged zero to two years. ${ }^{(1)}$ Even with a better life expectancy, more public care policies that provide care of child development are needed. ${ }^{(3)}$ It is believed that there are over $\mathbf{2 0 0}$ million children worldwide under five years who are at risk in relation to the development until adulthood. ${ }^{(3,4)}$

Child development is considered a process that starts from intrauterine life and involves physical growth, neurological maturation and building skills in cognitive, social, behavioral and affective areas of the infant, ${ }^{(5)}$ making the child competent to answer your needs. During this period occur important motor, physical, mental and social formations, as there is increased brain plasticity, which benefits the development of all the potentialities at this stage. Nevertheless, the normal development depends on the exploration of one's body and movements as well as the environment in which the infant is inserted. ${ }^{(6-8)}$

Among the typical motor development (TMD), the neck control is consider as being of great importance. ${ }^{(9)}$ Although there is no consensus on what the best position for stimulation of neck control, ${ }^{(10)}$ it is evidenced in the literature the positive association between the prone position and the TMD according to the age of the infants, ${ }^{(11-14)}$ either for the acquisition of neck control or the support of upper limbs. ${ }^{(14,15)}$

The experience in a position can interfere in the sequence and in the mechanism of the motor milestones, due to increased interaction of the child with the environment. ${ }^{(11,12)}$ Since the motor skills are highly influenced by cultural factors, is commonly perceived the resistance of maternal practice in placing the infant in the prone position. ${ }^{(16)}$ This resistance may be related to the risk of sudden death, ${ }^{(17,18)}$ discomfort shown by infants not adapted to the position, ${ }^{(13,16)}$ and the asphyxia during sleep. ${ }^{(19)}$

To evaluate the motor development (MD), the Alberta Infant Motor Scale (AIMS) has been widely used in children in Brazil. ${ }^{(20)}$ This provides high interrater and test/retest reliability,

Corresponding Author: Name: Tamiris Beppler Martins. E-mail: tamirismartins@outlook.com. Address: Rua Vidal Gregório Pereira, 363, Estreito, Florianópolis (SC), Brazil, CEP: 88095-030.

${ }^{1}$ Universidade estadual de Santa Catarina (UDESC), Florianópolis (SC), Brazil.

Full list of author information is available at the end of the article.

Financial support: There was no financial support for this study.

Submission date 25 July 2016; Acceptance date 2 October 2016; Publication online date 20 October 2016 
the sensitivity varies from 77,3 to $86,4 \%$ at four months and the specificity is $65,5 \%$ at eight months, ${ }^{(21)}$ these properties indicated a good level of instrument homogeneity. ${ }^{(22,23)}$

Furthermore, among the existing evaluation methods, kinematic analysis of human movement is widely used to quantify the movement and is commonly used in the evaluation of rehabilitation effects on motor control development of children and adults. ${ }^{(24-27)}$ However, in children, it is considered an important tool for understanding the acquisition and development of motor skills of infants. ${ }^{(28,29)}$

Because of that, it is believed that the application of AIMS to evaluate the MD, correlated with kinematics for assessment of postural and upper limbs alignment, can complement and provide satisfactory results for the scientific and clinical level, as until now no articles were found in the literature that related these two methods of evaluation.

Thus, the study aims to investigate the association between kinematic variables related to cervical control and upper limb support, with age and motor development in the prone position of typical children by AIMS.

\section{METHOD}

This study was approved by the Research Ethics Committee at $61 / 2010$ protocol and presented cross-sectional design, for convenience sample in a private hospital in Florianopolis, Santa Catarina.

Infants with TMD between one and four months old were studied. Inclusion criteria were: Children from one to four months ( \pm 7 days) with gestational age between 37 and 42 weeks, Apgar Score greater than seven in the fifth minute and birth weight greater than $2.5 \mathrm{~kg}$. Exclusion criteria were: children who had any neurological or musculoskeletal impairment and those who had percentile lower than $25 \%$ in motor assessment by AIMS.

\section{Instruments}

An anamnesis form, which contained personal data of the responsible for the child and the infant data (gestational period and months of life), was used for the evaluation of children. Body mass was measured by a digital balance from Tech Line and the measurement of body height was by an inelastic tape with accuracy of $1 \mathrm{~mm}\left(\right.$ ISP $\left.{ }^{\circledR}\right)$.

To evaluate the MD, was used the AIMS. ${ }^{(30)}$ The alignment of the head, upper body and upper limb was evaluated from two-dimensional kinematic analysis. We used: a) Tatami $1.5 \times 1.0 \times 0.4$ m (length, width, height); b) black spherical markers $(0.25 \mathrm{~cm}$ in diameter) positioned in the following anatomical points in the sagittal right plane: two points with a fixed distance of $1 \mathrm{~cm}$ were placed parallel and adjacent to the pinna; acromion; iliac crest; lateral epicondyle of the humerus; midpoint between the styloid process of the radius and ulna (Figure 1), fixed with Micropore ${ }^{\circledR}$ tape; c) A digital camera CASIO ${ }^{\circledR}$ Exilim EXFH20 with acquisition rates of $60 \mathrm{~Hz}$, positioned in the sagittal plane; d) aluminum tripod WFWT 3560 (0.75m tall), positioned $0.85 \mathrm{~m}$ from the tatami; e) TV set CCE $^{\circledR}$ HPS 1492 of 14 inches; g) DVD Player BAK ${ }^{\circledR}$ Japan; h) Software Ariel Performance Analysis System ${ }^{\circledR}$ (APAS); f) DVDs and sound and bright toys, suitable to the ages of the participants, were positioned $0.85 \mathrm{~m}$ from the infant. (14)

\section{Data collection procedure}

Parents or guardians of infants were informed about the study objectives and the evaluation to be conducted. Verbal and written consent was requested. After clarification and agreement, was requested the signature of assisted consent.

Data were collected for identification and assessment of motor development (MD), followed by the kinematics evaluation of the cervical extension movement as response to visual and auditory stimuli.

To perform the kinematics evaluation, the infant was placed in the prone position. The visual and auditory stimuli were made from DVDs and conducive toys suitable to the ages, with duration of $10 \mathrm{~s}$. To be considered valid, the infant needed to perform the extension of the head. The first and second month could be related to a smaller range of motion.

To better location and attachment of the markers, as well as the visualization of the movements during clinical assessments, the infants remained with the clothes from the waist down. All evaluations were performed in the laboratory environment, bright, with a pleasant temperature and with controlled and restricted access of people.

\section{Data Processing and Analysis}

The kinematic data were filtered with low-pass filter with a cutoff frequency of $6 \mathrm{~Hz}$. After visual inspection, frame by frame, using the APAS software, we analyzed three attempts of kinematics evaluation, in which it was determined the maximum cervical extension period conducted by a child. From it, was selected the range of 1 second (60 frames), among which the 31 frame always corresponded to the peak extension of the head.

After obtaining this interval, was calculated the average of the head alignment of the three attempts at each position evaluated, average of the upper body alignment, average of the upper limb alignment and average of the upper limb support, for later association of kinematic data with evaluation of MD.

The angular value of the head alignment was characterized as a segment angle from the intersection between two positioned markers at a fixed distance of $1 \mathrm{~cm}$, parallel and adjacent to the pinna with a horizontal line. Cervical correction corresponds to an angle of 90 degrees (Figure 1).

For the upper body alignment, was held the junction between the markers of the iliac crest and acromion with a horizontal line. The greater the extension of the trunk segment, the greater the angle value obtained; there were 


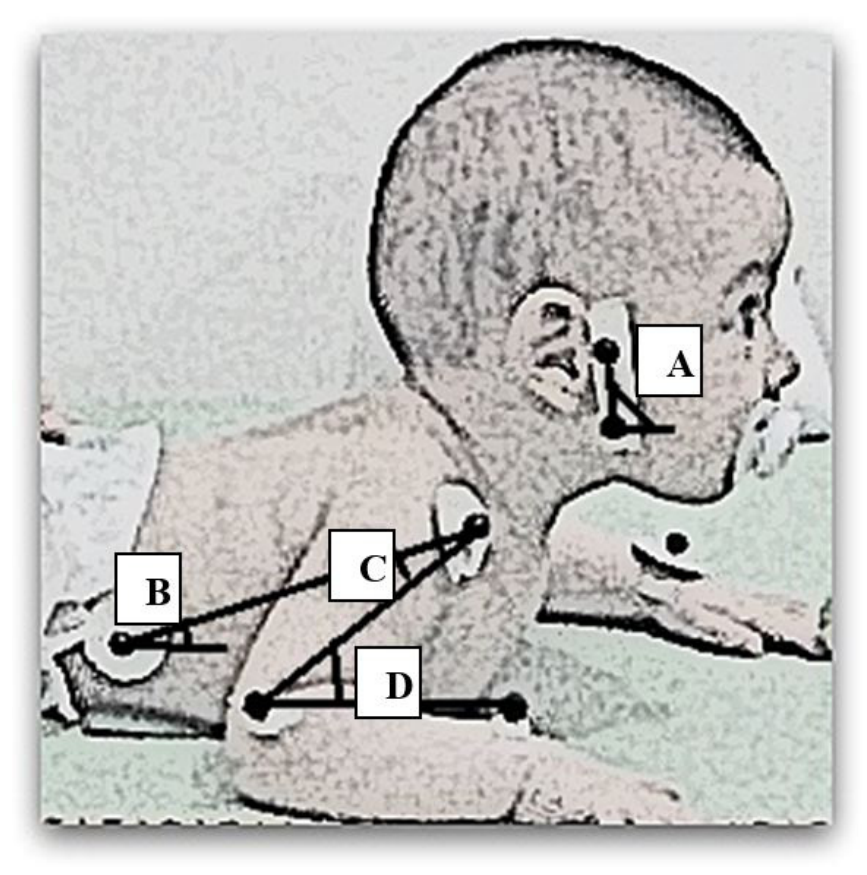

Figure 1. Measured angles in the sagittal plane: A) Alignment of the head; B) Alignment of the trunk; C) Alignment of the upper limb; D) Upper limb support.

positive angle values when the acromion was higher than the iliac crest (Figure 1).

The alignment of the upper limb was calculated from the junction between the markers of the iliac crest, the acromion and the lateral epicondyle of the humerus. When the lateral epicondyle of the humerus was displaced posteriorly in the direction of a shoulder extension, passing the marker of the iliac crest, the angle value obtained was negative (Figure 1). There were positive angle values when the child remained with the elbow on the mat with shoulder flexion (Figure 1).

The upper limb support was analyzed from the intersection between the acromion, lateral epicondyle of the humerus and the midpoint between the radius and ulna styloid process. The closer the acromion marker was of the radius and ulna styloid process, the lower was the observed angular value (Figure 1).

\section{Statistical analysis}

Descriptive data are reported as median, average, standard deviation and confidence interval for the mean. The analysis of the data normality was performed using the Shapiro-Wilk test and the data homogeneity by the Levene test. The Pearson and Spearman correlation coefficient were used to examine the association between the variables. It was adopted that the $R$ value lower than 0.2 indicates a very low association, between 0.2 and 0.39 a low association, between 0.4 and 0.69 a moderate association, between 0.89 and 0.7 a high association and between 0.9 and 1.0 a very high association.
The statistical program used was the Statistical Package for Social Sciences (SPSS) version 20.0 for Windows, for all procedures was adopted the significance level of $5 \%(p<0.05)$.

\section{RESULTS}

We evaluated 44 infants, in which 14 of them were excluded for presenting percentiles below $25 \%$ in AIMS. 30 typical infants ( 20 male and 10 female) with MD suitable for their age were included in the study (Table 1).

According to the motor assessment in the prone position and performance score by AIMS, the results are shown in Table 2, from average, total percentile and standard deviation, as well as the average value and standard deviation of the kinematic variable, inclination of the head.

Table 3 shows the relation between the variables: age, AIMS in the prone position and the kinematics variable (inclination of the head) with kinematics variables upper body extension, angle of the elbow and shoulder. It was observed that the age variable has a high positive correlation with the inclination of the head and a moderate association with the upper body extension and the angle of the elbow. According to the inclination of the head kinematic variable, there was a moderate positive association with the prone position assessed by AIMS and a moderate positive association with the upper body extension. The other variables showed no statistically significant associations.

Table 1. Median, minimum and maximum values of data that characterize the sample of the study $(n=30)$.

\begin{tabular}{lccc}
\hline & MED & MIN & MAX \\
\hline Age (days) & $\mathbf{7 6}$ & $\mathbf{2 8}$ & 132 \\
Weight (kg) & 6.0 & 4,0 & 8.0 \\
Length (cm) & 58 & 52 & 67 \\
Cephalic & 39.2 & 35 & 44 \\
perimeter (cm) & & & \\
Apgar 1 & 9 & 7 & 9 \\
Apgar 5 & 9 & 8 & 10 \\
\hline * MED = Median; MIN = Minimum; MAX = Maximum.
\end{tabular}

Table 2. Average value and standard deviation of the Alberta Infant Motor Scale (AIMS) in the prone position, the total average value and standard deviation of the Alberta Infant Motor Scale (AIMS) and average values and standard deviation of the kinematics inclination of the head variable $(n=30)$.

\begin{tabular}{lccc}
\hline & AIMS Prone & AIMS & $\begin{array}{c}\text { Inclination of } \\
\text { the Head }\end{array}$ \\
\hline Average & 4.4 & 11.8 & 34.4 \\
Percentile & - & 69.2 & - \\
$\begin{array}{l}\text { Standard } \\
\text { deviation }\end{array}$ & 1.6 & 2.5 & 3.2 \\
\hline
\end{tabular}


Table 3. Association between the kinematic variables (inclination of the head, upper body extension, angle of the shoulder and angle of the elbow) with the age, evaluation of motor development by subscale test of AIMS and cervical alignment with kinematic analysis $(n=30)$.

\begin{tabular}{lllc}
\hline & \multicolumn{1}{c}{ Age } & AIMS Prono & Kinematics head \\
\hline Head & $0.73(* *)$ & $0.66(* *)$ & - \\
Upper body & $0.64(* *)$ & $0.52(* *)$ & $0.50\left({ }^{* *}\right)$ \\
Shoulder & 0.14 & 0.25 & 0.17 \\
Elbow & $0.46\left(^{*}\right)$ & $0.39\left(^{*}\right)$ & $0.37\left(^{*}\right)$ \\
\hline
\end{tabular}

Pearson correlation; ${ }^{*} p<0,05 ;{ }^{* *} p<0,01$.

\section{DISCUSSION}

All evaluated infants showed up with the same potential for $\mathrm{MD}$, once the birth data presented within the normal range according to the reference curves of the National Center for Health Statistics, approved by the World Health Organization. (31)

Some factors are pointed out as higher risk for child development, including: low socioeconomic status, absence or precariousness of preventive action policies in public health, weak family ties, as an inappropriate relationship between parents and children, ${ }^{(7,32)}$ higher maternal age, lower Apgar in the 5 o minute, male children, lower weight gain in pregnancy and unemployed mothers. ${ }^{(33)}$

In this study there were no neonatal, postpartum and pregnancy complications. However, 14 children were excluded from the study due to the percentile lower than $25 \%$ by AIMS, ${ }^{(30)}$ which can be justified by the lack of stimulus received, resulting in a lower motor performance of healthy children, as the motor behavior is related to the context in which the child is inserted. ${ }^{(34)}$ Furthermore, the fear of caregivers with the prone position ${ }^{(12)}$ may be associated with this fact, because when avoided positioning in prone, the acquisition of antigravity activities may take longer. ${ }^{(13,35)}$

Infants in the study obtained MD appropriate to the age. This is considered a continuous and sequential process ${ }^{(28)}$ and it is expected that the motor potential of the child increases with the passing of months. This corroborates with Heck et al., (14) once this study showed motor evaluation of the prone position and month variables with a positive association with the inclination of the head, upper body and elbow extension.

When the infant remains awake in the prone position, tend to have better scores in the prone and sitting position by AIMS, ${ }^{(13,36,37)}$ which is associated with higher requirement of extensor muscles ${ }^{(37)}$ and features the gradual acquisition of motor skills in high positions. ${ }^{(13,36,37)}$

There was an angular increase in kinematic variable of the upper limb support angle which increases over the months, as well as the inclination of the head showed moderate positive association with the upper body extension and low association with the angular elbow value. Because of the cervical and trunk stability, the upper limb support is gradually positioned more anteriorly, ${ }^{(15)}$ which were also seen in this study. Infants with motor abnormalities may have limitations of scapular and upper limbs mobility because of the weakness of cervical and abdominal flexors, ${ }^{(38)}$ such changes is related with prolonged stay in supine, which is a negative factor for MD. ${ }^{(39)}$ However, the time spent in each posture was not controlled in this study.

Also, was found positive association between the AIMS score in the prone position with the inclination of the head, upper body and elbow extension. This may be associated with the practice of the child in the posture, because the prone position when stimulated promotes increased of cervical control and increased of discharge of weight in the upper limbs. (14) This posture requires activation of the extensor muscles to a stable postural control of the head and body by the child. (37) When increasing the cervical stability, upper body and members control will also increase. Since the first week of life, the child can already raise his head, activating the antigravity muscles of the neck, ${ }^{(40)}$ but they do not have control of the cervical muscles yet.

Some factors like the decrease in physiological flexor tone, the growth of the neck length and lack of synergy in the coactivation of the neck muscles ${ }^{(6)}$ may be related to variations in rectification of the head of the children from the first to the third month. In the fourth month the children has full cervical control, with improved postural stability, as well as facility to keep their head rectified against the action of gravity in a longer period of time.

The increased of motor skills of weight support against gravity is favored by the prone position, since joins later with the other positions, as supine, sitting ${ }^{(13,37)}$ and standing ${ }^{(6)}$ plus the manual skills. ${ }^{(38)}$ The MD is influenced by numerous factors, ${ }^{(41)}$ thus the experience offered to the child becomes critical to their learning and their overall development. ${ }^{(42)}$

\section{CONCLUSION}

It can be concluded in this study that there is a positive association between evaluated variables, which represents increasing in the motor performance in the prone position according to the months of age of infants and the cervical control and upper limb support are enhanced. Thus, it is suggested that kinematic variables can be used to measure the infants' motor performance in the first months of life, as there is concordance of it with the MD scale used in this study.

\section{AUTHOR'S CONTRIBUTIONS:}

$\mathrm{MM}$ : Conception and development (from the idea to the research and article, created the hypothesis). TBM, MM, ADR: Methodological design (planning of methods to generate results). MWL, CJ: Supervision (responsible for the organization and execution of the project and writing of the manuscript). TBM, MM, ADR: Collection and processing of data (responsible for experiments, patients, organization of data). MM: Analysis/interpretation (responsible for statistical analysis, evaluation and presentation of results). MM, TBM, ADR: Literature survey (participated in bibliographical research and survey of articles). MM, TBM, ADR, CJ, GMS, MWL: Writing (responsible for writing a substantive part of the manuscript). MM, TBM, ADR, MWL, CJ, GMS: Critical review (reviewed the intellectual contents of the manuscript before the final presentation). 


\section{CONFLICT OF INTEREST:}

The authors declare that they have no conflicts of interest.

\section{AUTHOR DETAILS}

${ }^{2}$ Universidade federal de São Paulo (UNIFESP), São Paulo (SP), Brazil.

\section{REFERENCES}

1. Instituto Brasileiro De Geografia E Estatística (IBGE). Síntese de Indicadores Sociais: Uma Análise das Condições de Vida da População Brasileira: 2010, p. 149.

2. Instituto Brasileiro De Geografia E Estatística (IBGE). Brasil em Síntese. 2013. Disponível em: <http://brasilemsintese.ibge.gov.br/populacao/ esperancas-de-vida-ao-nascer>. Acesso em: 27 maio 2013.

3. Organização Pan-Americana Da Saúde (OPAS). Manual para vigilância do desenvolvimento infantil no contexto da AIDPI. Washington: OPAS, 2005. Impresso.

4. Dornelas LF, Duarte NMC, Magalhães LC. Atraso do desenvolvimento neuropsicomotor: mapa conceitual, definições, usos e limitações do termo. Revista Paulista de Pediatria. 2015;33(1):88-103.

5. Miranda LP, Resegue R, Figueiras ACM. A criança e o adolescente com proble $\neg$ mas do desenvolvimento no ambulatório de pediatria. J Pediatr. 2003;79:33-42.

6. Lima CD, Carvalho RP, Barros RML, Tudella E. Dois métodos diferentes para análise cinemática dos movimentos de cabeça durante a coordenação viso-cefálica de lactentes. Rev. Bras. Fisioter. 2008;12(5):425-31.

7. Saccani S, Brizola E, Giordani AP, Bach S, Resende TL, Almeida CS. Avaliação do desenvolvimento neuropsicomotor em crianças de um bairro da periferia de Porto Alegre. Sci Med. 2007;17(3):130-7.

8. Nascimento R, Piassão C. Avaliação e estimulação do desenvolvimento neuropsicomotor em lactentes institucionalizados. Revista Neurociência. 2010;18(4):469-478.

9. Pérez $\mathrm{M}$, Rodríguez $\mathrm{F}$. Relación entre la postura en prono y la adquisición del sostén cefálico a los 3 meses. An Pediatr (Barc). 2013;79(4):241-247.

10. Ratliff-Schaub K, Hunt CE, Crowell D, Golub H, Smok-Pearsall S, Palmer $\mathrm{P}$, et al. Relationship between infant sleep position and motor development in preterm infants. J. dev. Behav. pediatr. 2001;22:293-9.

11. Campos D, Santos DCC. Controle postural e motricidade apendicular nos primeiros anos de vida. Fisioterapia em Movimento. 2005;18(3):71-77.

12. Silva PL, Santos DCC, Gonçalves BMG. Influência de práticas maternas no desenvolvimento motor de lactentes do 60 ao 12ㅇ meses de vida. Revista Brasileira de Fisioterapia. 2006; 10(2):225-31.

13. Dudek-Shriber L, Zelazny S. The effects of prone positioning on the quality and acquisition of developmental milestones in four-month-old infants. Pediatric Physical Therapy. 2007;19:48-55.

14. Heck APF, Martinello M, de Medeiros DL, Coelho JJ, Ries LGK. Effect of the inclination of support in cervical and upper limb development. Fisioterapia em Movimento. 2014;27(4):601-609.

15. Dimimitrijevic L, Bjelakovic B. Development of cardinal motor skills in the first year of life. Acta Fac. Med. Naiss. 2004;21(4):253-7.

16. Saccani R, Valentini NC. Analysis of motor development of infants from zero to 18 months of age: representativeness of the motors items of the alberta infant motor scale by age and posture. Revista Brasileira de Crescimento e Desenvolvimento Humano. 2010;20:711-722.

17. Yiallourou SR, Walker AM, Horne RS. Effects of sleeping position on development of infant cardiovascular control. Arch Dis Child. 2008;93(10):868-872.

18. Wong FY, Witcombe NB, Yiallourou SR, Yorkston S, Dymowski AR, Krishnan L, et al. Cerebral oxygenation is depressed during sleep in healthy term infants when they sleep prone. Pediatrics. 2011;127(3).
19. Formiga CKMR, Pedrazzani ES, Tudella E. Desenvolvimento motor de lactentes pré-termo participantes de um programa de intervenção fisioterapêutica precoce. Revista Brasileira de Fisioterapia. 2004;8(3):23945 .

20. Medeiros DL, Pacheco SCS, Graefing BCF, Sperandio FF, Martinello M, Ries LGK. Propriedades Psicométricas de Escalas de Desenvolvimento Motor Infantil em Brasileiros. Pediatria Moderna; 2015.

21. Herrero D, Gonçalves H, de Siqueira AAF, de Abreu LC. Escalas de desenvolvimento motor em lactentes: Test of Infant Motor Performance e a Alberta Infant Motor Scale. Rev. Bras. Cresc. e Desenv. Hum. 2011;21(1):122-132.

22. Valentini NC, Saccani R. Escala Motora Infantil de Alberta: validação para uma população gaúcha. Rev Paul Pediatr 2011; 29:231-8.

23. Valentini NC, Saccani R. Brazilian Validation of the Alberta Infant Motor Scale. Phys Ther 2012; 92:440-7.

24. Pieruccini-Faria F, Menuchi MRTP, Vitorio R, Gobbi LTB, Stella F, Gobbi S. Parâmetros cinemáticos da marcha com obstáculos em idosos com doença de Parkinson, com e sem efeito da levodopa: um estudo piloto. Rev Bras Fisioter. 2006;10(2):233-9.

25. Lindquist $A R R$, Prado $C L$, Barros RML, Mattioli R, Costa PHL, Salvini TF. Gait training combining partial body weight support, a treadmill, and functional electrical stimulation: effects on poststroke gait. Phys Ther. 2007;87(9):1144-54

26. Toledo DR, Rinaldi NM, Barela JA. Controle postural em crianças: efeito da manipulação da informação visual discreta. Revista Brasileira de Comportamento Motor. 2006;1(1):82-8.

27. Godoi D, Barela JA. Body sway and sensory motor coupling adaptation in children: effects of distance manipulation. Dev Psychobiol. 2008;50(1):77-87.

28. Rocha NA, Silva FP, Tudella E. Influência do tamanho e da rigidez dos objetos nos ajustes proximais e distais do alcance de lactentes. Rev Bras Fisioter. 2006;10(3):263-9.

29. Carvalho RP, Tudella E, Caljouw SR, Savelsbergh GJ. Early control of reaching: effects of experience and body orientation. Infant Behav Dev. 2008;31(1):23-33

30. Piper MC, Darrah J. Motor assessment of the developing infantile. United States of America: W.B. Saunders Company; 1994.

31. World Health Organization [website]. 2006 [cited2011, Aug 14]. Available from: http://www.who.int/countries/bra/es/

32. Andrade KC, Souza SB, Szarfarc SC. Desenvolvimento neuromotor e dentição de crianças atendidas em serviços públicos de saúde do Brasil, no primeiro ano de vida. Rev bras crescimento desenvolv hum. 2007;17(2):37-44

33. Braga AKP, Rodovalho JC, Formiga CKMR. Evolução do crescimento e desenvolvimento neuropsicomotor de crianças pré-escolares de zero a dois anos do município de Goiânia (GO). Rev bras crescimento desenvolv hum. 2011; 21(2): 230-9.

34. Halpern R, Figueiras A. Influências ambientais na saúde mental da criança. Jornal de Pediatria. 2004;80(2):104-10.

35. Majnemer A, Barr RG. Influence of supine sleep positioning on early motor milestone acquisition. Dev Med Child Neurol. 2005;47(6):370376.

36. Salls JS, Silverman LN, Gatty CM. The relationship of infant sleep and play positioning to motor milestone achievement. Am J Occup Ther. 2002;56(5):577-80.

37. Formiga CKMR, Cezar MEN, Linhares MBM. Avaliação longitudinal do desenvolvimento motor e da habilidade de sentar em crianças nascidas prematuras. Fisioter. pesq. 2010;17(2):102-7.

38. Prado C, Vale LA. Fisioterapia neonatal e pediátrica. Barueri: Manole, 2008. 564p. 
39. Miller LC, Johnson A, Duggan L, Behn M. Consequences of the "back to sleep" program in infants. Journal of pediatric nursing. 2011;26(4):364368.

40. Kapandji IA. The physiology of the joints: the trunk and vertebral column. Edinburgh: Churchill Livingstone; 2000.
41. Charitou S, Asonitou K, Koutsouki D. Prediction of infant's motor development. Proc Soc Behav Scienc. 2010;9:456-461.

42. Libertus K, Landa RJ. The Early Motor Questionnaire (EMQ): a parental report measure of early motor development. Infant Behav.2013;36(4):833-842. 